\title{
"Antecedents of attitudes towards and usage behavior of mobile banking amongst Generation Y students"
}

\begin{tabular}{|c|c|}
\hline AUTHORS & $\begin{array}{l}\text { Marko van Deventer (Dttps://orcid.org/0000-0002-0000-4699 } \\
\text { Natasha de Klerk } \\
\text { Ayesha Bevan-Dye }\end{array}$ \\
\hline ARTICLE INFO & $\begin{array}{l}\text { Marko van Deventer, Natasha de Klerk and Ayesha Bevan-Dye (2017). } \\
\text { Antecedents of attitudes towards and usage behavior of mobile banking amongst } \\
\text { Generation Y students. Banks and Bank Systems, 12(2), 78-90. } \\
\text { doi:10.21511/bbs.12(2).2017.08 }\end{array}$ \\
\hline DOI & http://dx.doi.org/10.21511/bbs.12(2).2017.08 \\
\hline RELEASED ON & Friday, 23 June 2017 \\
\hline RECEIVED ON & Wednesday, 29 March 2017 \\
\hline ACCEPTED ON & Wednesday, 31 May 2017 \\
\hline LICENSE & $\begin{array}{l}(c) \text { EY-NG } \\
\text { This work is licensed under a Creative Commons Attribution-NonCommercial } 4.0 \\
\text { International License }\end{array}$ \\
\hline JOURNAL & "Banks and Bank Systems" \\
\hline ISSN PRINT & $1816-7403$ \\
\hline ISSN ONLINE & $1991-7074$ \\
\hline PUBLISHER & LLC "Consulting Publishing Company "Business Perspectives" \\
\hline FOUNDER & LLC "Consulting Publishing Company "Business Perspectives" \\
\hline
\end{tabular}

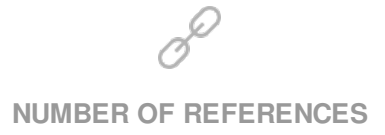

78
NUMBER OF FIGURES

1
NUMBER OF TABLES

5

(C) The author(s) 2023. This publication is an open access article. 
Marko van Deventer (South Africa), Natasha de Klerk (South Africa), Ayesha Bevan-Dye (South Africa)

\title{
Antecedents of attitudes towards and usage behavior of mobile banking amongst Generation $Y$ students
}

\begin{abstract}
Despite the benefits that mobile banking has to offer, coupled with positive mobile penetration rates, the use of mobile devices to perform banking transactions and access financial information is not as widespread as expected. The significantly sized Generation Y cohort is a rewarding market segment for retail banks. In South Africa, however, this cohort's mobile banking adoption is largely under-researched. Understanding the antecedents that positively influence Generation Y students' attitudes towards and usage behavior of mobile banking will assist retail banks in their efforts to tailor their business and marketing strategies effectively towards this cohort, and in doing so, foster increased acceptance of their mobile channels. As such, the purpose of this study was to extend the technology acceptance model (TAM) and determine the influence of perceived ease of use, relative advantage, subjective norms, perceived behavioral control, perceived integrity and the perceived system quality of mobile banking on South African Generation Y students' attitudes towards and usage behavior of mobile banking. Following a descriptive research design, selfadministered questionnaires were completed by a non-probability convenience sample of 334 students registered at the campuses of three registered public South African universities located in the Gauteng province. Data analysis included correlation analysis and structural equation modeling. The findings suggest that while perceived ease of use, perceived integrity and the perceived system quality predict Generation Y students' mobile banking usage behavior, subjective norms, perceived behavioral control and the perceived relative advantage of mobile banking predict attitudes towards mobile banking, which, in turn, predict their mobile banking usage behavior.
\end{abstract}

Keywords: mobile banking attitude, mobile banking behavior, technology acceptance model (TAM), Generation Y students, South Africa.

JEL Classification: G20, M31, O30.

Received on: $29^{\text {th }}$ of March, 2017.

Accepted on: $31^{\text {th }}$ of May, 2017.

\section{Introduction}

Prior to Internet connectivity, the banking sector was made up of a large number of relatively small retail banks operating in distinct geographical domestic markets. Moreover, customers completed their banking transactions with the assistance of a branch service employee (Arnaboldi and Claeys, 2008). Although this traditional business model of branch banking is instrumental to a retail bank's success and while it remains an essential distribution channel (Kanchan et al., 2012), retail banks are constantly challenged with transforming and integrating their distribution channel mix (Cox et al., 2008). Furthermore, retail banks are challenged with growing their business operations (Martins et al., 2014) and bank market share (Arnaboldi and Claeys, 2008), lowering operating costs (Martins et al., 2014) and improving business performance (Ernst and Young, 2009), while simultaneously trying to satisfy demanding customers (Ernst and Young,

(c) Marko van Deventer, Natasha de Klerk, Ayesha Bevan-Dye, 2017. Marko van Deventer, Dr., School of Economic Sciences, North-West University, South Africa.

Natasha de Klerk, Prof., School of Economic Sciences, North-West University, South Africa.

Ayesha Bevan-Dye, Prof., School of Economic Sciences, North-West University, South Africa.

This is an Open Access article, distributed under the terms of the Creative Commons Attribution-NonCommercial 4.0 International license, which permits re-use, distribution, and reproduction, provided the materials aren't used for commercial purposes and the original work is properly cited.
2017). In addition, retail banks operate in an environment that is highly competitive (Arnaboldi and Claeys, 2008) and ever changing due to advances in information technology (Ernst and Young, 2017). Additionally, retail banks have to account for the momentous shift in consumer behavior brought about by the digital revolution that continuously impact the way businesses and customers transact (Standard Bank, 2015).

The change in consumer behavior and the development and introduction of new technologies and banking innovations widens the gap between the banking processes of the past and future expectations (Marous, 2013). To breach this gap and ensure that retail banks stay current, significantly innovate and transform for the future $(\mathrm{PwC}, 2014)$, retail banks are increasingly focused on delivering banking services through digital channels (Arnaboldi and Claeys, 2008). One such a digital banking channel is mobile banking, which continues to play an important role in retail banks' digital strategies.

Mobile banking has advanced from pull-based short message service (SMS) banking in the early 1990s to high-end mobile applications downloaded onto customers' mobile devices, such as mobile phones, smart phones and tablets (KPMG, 2015a). The banking sector acknowledges the economic and social benefits associated with mobile banking. Mobile banking offers retail banks the avenues and opportunities to extend banking penetration and reach into 
untapped markets (Ernst and Young, 2009), including unbanked and low-income markets (Lee et al., 2007), reduce operating costs (PwC, 2011), reach customers in remote locations, overcome infrastructure limitations and improve efficiencies. Mobile banking also offers customers the benefit of accessing financial services quickly, easily, conveniently and more cost effectively (Ernst and Young, 2009) compared to branch banking.

Globally, including in emerging economies such as South Africa, mobile banking is said to be one of the fastest growing markets (Püschel et al., 2010; Madu$\mathrm{ku}, 2011)$. This may be attributed to the unprecedented growth in mobile penetration and the ever-growing usage of the Internet on mobile handsets. According to the GSMA mobile economy report, global mobile penetration stood at 65 percent in 2016 and is expected to increase to 73 percent in 2020, and mobile internet penetration recorded at 48 percent in 2016 is anticipated to reach 60 percent by 2020 (GSMA, 2017). In terms of mobile banking, the global mobile banking penetration rate was recorded at roughly 42 percent in 2015. The number of mobile banking users is expected to increase from 0.8 billion users in 2014 to 1.8 billion users in 2019 , which represents a significant increase of 119 percent (KPMG, 2015b). This increase in the mobile banking penetration rate suggests an increase in banking penetration, denoting that less people are unbanked.

In South Africa, a mobile penetration rate of 160 percent was recorded in 2016 (BuddeComm, 2017) of which 60 percent are smartphones. Despite the benefits mobile banking has to offer, coupled with positive mobile penetration rates, the use of mobile devices to perform banking transactions and access financial information is not as widespread as expected with a mobile banking penetration rate of 26 percent in 2016 (Shezi, 2016). In contrast, banking penetration reached 75 percent in 2014 and increased to 77 percent in 2015 (FinScope South Africa, 2015). These gaps between mobile penetration, mobile banking penetration and banking penetration suggests that while many customers are banked and have a mobile phone, many still do not use mobile banking. As such, South Africa is a fertile environment for mobile banking adoption, and retail banks have an interest to see continued growth in their mobile channels. Retail banks can achieve this growth through positively influencing customers' attitudes towards and behavior of mobile banking, including customers of the significantly sized and attractive Generation Y market segment.

In generational studies, the youth are delineated as Generation Y (Eastman and Liu, 2012), and consists of a cohort of individuals born between 1986 and 2005 (Markert, 2004). In 2016, the South African
Generation Y cohort encompassed almost 38 percent of the country's total population of 55 million people (Statistics South Africa, 2016). Generation Y is the first generation to have access to a number of multimedia platforms, convergent technologies, mobile phones and the Internet (Schlitzkus et al., 2010). As such, this digitally connected generation expects to obtain information at a rapid pace (Kane, 2016). With regards to banking, South African Generation Y, many of whom are banking for the first time (KPMG South Africa, 2014), drive digital finance services (IT news Africa, 2015) and demand the newest innovations to satisfy their banking needs (KPMG South Africa, 2014). This is because customers of this generation prefer to take a more active control of the transaction process. In addition, they are categorized as early adopters who are comfortable with using self-service digital banking channels (IT news Africa, 2015). Therefore, Generation Y represents a market segment of significant value to retail banks. Furthermore, being comfortable with technology and technologically astute, suggests that Generation Y customers could possibly pave the way towards new technology adoption, such as mobile banking.

Despite the low mobile banking penetration in South Africa, there is a dearth of published studies in the South African context. In addition, the Generation Y cohort's mobile banking adoption is largely underresearched in the country. As such, the purpose of this study was to extend the technology acceptance model (TAM) to determine the influence of perceived ease of use, relative advantage, subjective norms, perceived behavioral control, perceived integrity and perceived system quality of mobile banking on South African Generation Y students' attitudes towards and usage behavior of mobile banking. This study is specifically focused on tertiary students, as the tertiary student portion of this cohort, who typically include individuals aged between 18 and 24 years (Special and Li-Barber, 2012), are likely to present as important role models among the country's wider Generation Y cohort, given the higher social standing that is generally associated with a tertiary qualification. In addition, graduates typically have a higher future earning capacity, which translates into a greater future disposable income and stronger spending power (Bevan-Dye and Akpojivi, 2015).

\section{Literature review and theoretical framework}

1.1. The technology acceptance model (TAM). The TAM was originally proposed by Davis (1986) in a doctoral thesis and formally published in 1989 (Davis, 1989). The TAM is an adaption of the Theory of Reasoned Action (TRA) (Koh et al., 2010) proposed by Fishbein and Ajzen (1975) and Ajzen and Fishbein (1980). The TRA is based on four precepts, namely attitude, subjective norm, 
behavioral intention and behavior, and theorizes that both attitude and subjective norm influence behavioral intention, which, in turn, predicts behavior. This theory is of theoretical and practical value and is "designed to explain virtually any human behavior" (Ajzen and Fishbein, 1980, p. 89). The TAM, propounded because of the success of the TRA in explaining behavior across a wide array of contexts (Maduku, 2013), is one of the most widely applied technology acceptance models and has proven to be a vigorous and influential theoretical model in predicting user behavior of new information technology (Tome et al., 2014). The popularity of the TAM among information system researchers may be attributed to the TAM focusing specifically on information technologies, its proven validity and reliability, and its magnitude of empirical support (Sharp, 2007).

The TAM comprises six causally related constructs, namely external variables, perceived ease of use, perceived usefulness or relative advantage, attitude, behavioral intention to use a technology or system and actual system usage behavior (Davis, 1989). According to the TAM, perceived ease of use and perceived usefulness influence an individual's attitude and subsequent behavioral intention to use a system (Surendran, 2012). Behavioral intention, in turn, predicts an individual's actual system usage behavior (Sharp, 2007). Perceived ease of use, perceived usefulness, attitude and behavioral intention represent the core functions of the TAM, whereas the external variables and actual system usage behavior are used as input to or output from the model (Erasmus et al., 2015). The influence of external variables on system usage behavior is mediated through individual beliefs and attitudes. An individual's belief relates to the subjective assessment that undertaking some behavior will have a particular outcome, whereas attitude is associated with an individual's favorable or unfavorable affective feelings about undertaking a behavior (Park, 2009). In the TAM, perceived ease of use and perceived usefulness are belief constructs. Both these constructs are indirectly influenced by external variables in strengthening an individual's belief that using a specific system could enhance their performance and through their belief that using a specific system (by implication, mobile banking) will be free of effort (Surendran, 2012).

Although there is overwhelming support in the literature concerning the suitability of the TAM in predicting and explaining usage behavior of several information technology systems, the aim of this study was to investigate a more complete set of antecedents of attitudes towards and usage behavior of mobile banking. Therefore, the model outlined is an extended TAM that includes the key constructs of perceived ease of use, perceived relative advantage (or perceived usefulness), attitude and usage behavior, as well as subjective norms, perceived behavioral control, the integrity of the mobile bank and the system quality of mobile banking.

\subsection{Attitudes towards and usage behavior of mo-} bile banking. An attitude is described as a learned predisposition to act in a consistently positive or negative manner regarding a particular object. Although individuals' attitudes develop with time and are usually consistent, some external factors may have an effect on and change individuals' attitudes. This indicates that while attitudes are long-term and lasting, they are subject to change (Schiffman et al., 2010). An attitude towards the use of a particular technology is influenced by an individual's opinion that its use will elicit a particular outcome. An individual's intention to perform a particular behavior is depended on the individual favorable evaluation of performing the behavior (Ajzen, 1991). Hence, an individual that displays a more positive attitude towards a certain behavior is more likely to adopt the behavior (Thornton et al., 2007). An attitude towards technology is an important factor to consider, particularly because it has a direct positive influence on usage behavior (Sommer, 2011). While the TAM proposes that attitude predicts an individual's behavioral intention to use a technology, which, in turn, predicts actual usage behavior (Guritno and Siringoringo, 2013), there is an agreement among researchers that attitude is an influential factor of actual behavior (Alsaijan and Dennis, 2009) and that attitude positively influences actual usage behavior (Lin, 2011; Mazhar et al., 2014). Consistent with these studies, this study theorizes that attitudes towards mobile banking positively influence mobile banking usage behavior.

1.3. Ease of use of mobile banking. Perceived ease of use is the degree to which an individual perceives a system as being straightforward and simple to use; that is, free of any effort (Davis, 1989). The more an individual views an innovation as being easy to use, the more likely the individual is to develop a positive attitude towards using it (Nor and Pearson, 2008). Perceived ease of use predicts attitudes in a number of studies (Gumussoy et al., 2007; Nor and Pearson, 2008; Guritno and Siringoringo, 2013). According to the TAM, attitude towards using a particular system or technology is determined by perceived ease of use (Guritno and Siringoringo, 2013). In line with international mobile banking studies (Lee, 2009; Wessels and Drennan, 2010; Akturan and Tezcan, 2012) and the TAM, this study hypothesizes that if mobile banking users consider mobile banking as being easy to use, they will likely display a positive attitude towards using it. 
1.4. Relative advantage of mobile banking. Perceived relative advantage (or perceived usefulness) is the degree to which an individual perceives a technological innovation as having more benefits and greater effectiveness than that of other innovations; that is, greater performance benefits and usefulness from using a particular system (Surendran, 2012). Individuals that perceive an innovation as having utility advantages are more likely to display a favorable attitude towards it (Nor and Pearson, 2008). Several studies (Lin, 2011; Sayid et al., 2012; Shanmugam et al., 2014) in the information technology domain confirm that perceived relative advantage predicts attitudes.Similar to perceived ease of use in the TAM, perceived relative advantage also predicts attitude towards using a specific system. In keeping with previously published mobile banking studies (Wessels and Drennan, 2010; Akturan and Tezcan, 2012; Khasawneh, 2015) and the TAM, this study postulates that should a user view mobile banking as useful and being able to improve their job performance, they will likely demonstrate a positive attitude towards using it.

1.5. Subjective norm. Subjective norm is described as the social pressure that an individual feels from important others to undertake a certain behavior (Niaura, 2013). Subjective norm also refers to the extent to which an individual perceives the attitudes of his or her family, friends, colleagues and peers to be positive or negative towards a specific behavior (Greaves et al., 2013). In the online environment, reference groups such as friends, family and peers have an influence on customers' initial adoption behavior (Nor and Pearson, 2008). Although the TAM omits subjective norm, this construct is relevant when considering an attitude towards usage and usage behavior of information technology, particularly because some individuals use technology to comply with the mandates or expectations of the people with whom they esteem in their personal frame of references, rather than their own feelings or beliefs about using it (Davis et al., 1989). Therefore, the model proposed in this study follows the hypotheses of previously published studies of a similar nature (Gao et al., 2012; Maduku, 2013), suggesting that a system user will likely display a positive attitude towards the use of a particular system because of the positive perceptions held by various social entities. As such, this study posits that subjective norms, which can comprise the perceptions of important others, such as friends, family or peers, positively influences a mobile banking user's attitude towards using it.

1.6. Perceived behavioral control. Perceived behavioral control is described as the extent to which an individual believes that a certain behavior is easy or difficult to perform, as well as his or her perceived ability to generate a positive outcome when undertaking the behavior (Ajzen, 1991). An internal and external factor influence these beliefs. The internal factor relates to self-efficacy, which is an individual's confidence in his or her ability to undertake the behavior. The external factor relates to facilitating conditions, which is an individual's perception of the available resources, such as a reliable Internet connection, necessary to engage in the behavior (Nor and Pearson, 2008). This study postulates that individuals who have self-confidence and the necessary resources to undertake mobile banking will likely develop a positive attitude towards mobile banking. Hence, perceived behavioral control positively influences attitudes towards mobile banking. This postulation is consistent with previous research findings (Crabbe et al., 2009; Saibaba and Murthy, 2013).

1.7. Integrity of the mobile bank. Integrity, in a retail banking context, is retail banks' honesty in their undertakings with their customers, their willingness to follow through on promises made, as well as their commitments towards safeguarding the online environment (Nor and Pearson, 2008). Customers who have used the physical infrastructure and services of a reputable retail bank are more likely to trust and use this retail bank's new digital banking channels, including mobile banking. The rules that govern the integrity of the mobile banking environment comprise the provision of up-to-date and reliable information, maintaining customer commitments and honoring the assurance of confidentiality of customers' personal information (Lin, 2011). While some studies (Sharif et al., 2005; Nor and Pearson, 2008) suggest that perceived integrity is an antecedent of trust, this study proposes that individuals that believe that their retail bank has the necessary integrity will likely demonstrate a positive attitude towards their digital channels, such as mobile banking. Hence, this study proposes that the perceived integrity of a retail bank with mobile banking channels positively influences attitudes towards mobile banking. Similar studies (Lin, 2011; Delafrooz et al., 2013; Galadima et al., 2014) are in agreement with this postulation.

1.8. System quality of mobile banking. System quality refers to the simplicity of use and navigation, visual appeal and the access speed of mobile banking (Gu et al., 2009). Given that certain mobile devices have small screens and problematic input methods, some mobile banking users may find it challenging to access their financial information and conduct banking activities. Retail banks are, therefore, increasingly focused on ensuring that their mobile banking interface is designed with a clear layout and a powerful navigation, and that their mobile system quickly prompts 
customers' responses (Zhou, 2011). In addition, it is important that the mobile banking system provides information that is relevant, sufficient, accurate and timely, and that structural assurances such as legal structures and technological advances are in place to secure the mobile system (Zhou, 2013). While the literature suggests that system quality is an antecedent of trust, an extensive review of the literature reveals two studies (Kleijnen et al., 2004; Olatokun and Owoeye, 2012) with empirical support that perceived system quality positively influences attitudes. Consistent with their findings, this study postulates that users will likely demonstrate a positive attitude towards mobile banking if the mobile banking system provides accurate information at a high speed, is safe and secure, as well as easy to navigate.

\section{Methodology}

2.1. Target population, sampling frame and sampling method. The target population relevant for this study was specified as Generation Y students aged between 18 and 24 years, registered at South African public higher education institutions (HEIs). The sampling frame consisted of a list of the 26 registered South African public HEIs, comprising 11 traditional universities, nine comprehensive universities and six universities of technology. Of the 26 HEIs, a judgment sample of three HEI campuses located in the Gauteng province was selected. Of these, one was a traditional university, one a comprehensive university and one a university of technology. Thereafter, a nonprobability convenience sample of 450 students across the three campuses was drawn. This sample sizeis in the range of other studies of a similar nature such as Akturan and Tezcan (2012) (sample size of 435) and Hanafizadeh et al. (2014) (sample size of 403).

\subsection{Research instrument and data collection} procedure. The required data were collected using a survey self-administered questionnaire. In accordance with the data required, the questionnaire included scaled items from published studies that were adapted to reflect attitudes towards and usage behavior of mobile banking. The Nor and Pearson (2011) Internet banking adoption scale was used to measure seven possible antecedents, namely attitudes towards mobile banking, perceived ease of use of mobile banking, subjective norms, perceived behavioral control, perceived integrity of the mobile bank, mobile banking usage behavior and perceived relative advantage of mobile banking, and comprised three items each. The Zhou (2011) initial trust in mobile banking scale was used to measure the perceived system quality of mobile banking, and comprised eight items. A six point Likert scale, ranging from strongly disagree (1) to strongly agree (6), was used to measure all the scaled responses. The questionnaire was accompanied by a cover letter, which provided an assurance of confidentiality pertaining to the information provided by the participant and included a section designed to gather the participants' demographical information.

In order to ensure the reliability of the questionnaire, a pilot study was done on a convenience sample of 59 students not included in the sample. A Cronbach alpha of 0.9 was recorded for the antecedents of attitudes towards and usage behavior of mobile banking scale, which is within the recommended level of 0.6 (Malhotra, 2010). This value suggests internal-consistency reliability (Pallant, 2010) of the scale. As such, the 29-scaled items were used to prepare the main survey questionnaire, which was administered to the main sample.

Lecturers at each of the three HEI campuses were contacted telephonically to request permission to conduct the survey. Once permission was granted, the participating lecturers were shown the questionnaire together with the ethics clearance certificate. Thereafter, field workers distributed the questionnaires to the students for voluntary completion at each of the three campuses.

\section{Results}

Of the 450 questionnaires administered, 334 complete and usable ones were returned, resulting in a response rate of 74 percent. The sample included more participants from a traditional university (37\%), followed by those who were from a comprehensive university (33\%) and a university of technology (30\%). All age groups specified in the target population were comprised in the sample. There were less male (42\%) than female (58\%) participants in the sample. The majority of the participants identified themselves as Africans $(84 \%)$, followed by those who identified themselves as White (11\%), Indian/Asian $(2.7 \%)$ and Coloured (2.4\%). There were more Sesotho speaking $(26 \%)$ participants in the sample, followed by those reporting their mother-tongue language as IsiZulu (15\%) and Setswana (13\%). The sample included participants from each of South Africa's nine provinces, with majority of the participants being from the Gauteng (57\%) province and the least from the Western Cape (2\%). The sample is described in Table 1. 
Table 1. Sample description

\begin{tabular}{|l|c|c|c|c|c|l|l|l|l|l|l|}
\hline \multicolumn{1}{|c|}{ Institution } & $\%$ & Age & $\%$ & Gender & $\%$ & Ethnicity & $\%$ & Language & $\%$ & Home province & $\%$ \\
\hline Traditional university & 37 & 18 & 7 & Male & 42 & African & 84 & Afrikaans & 9 & Eastern Cape & 2 \\
\hline Comprehensive university & 33 & 19 & 14 & Female & 58 & Coloured & 2 & English & 8 & Free State & 11 \\
\hline University of technology & 30 & 20 & 26 & & & Indian/Asian & 3 & IsiXhosa & 7 & Gauteng & 57 \\
\hline & & 21 & 25 & & & White & 11 & IsiZulu & 15 & KwaZulu-Natal & 3 \\
\hline & & 22 & 14 & & & & & Sepedi & 8 & Limpopo & 11 \\
\hline & & 23 & 9 & & & & & Sesotho & 26 & Mpumalanga & 6 \\
\hline & & 24 & 5 & & & & & Setswana & 13 & Northern Cape & 1 \\
\hline & & & & & & & & SiSwati & 4 & North-West & 7 \\
\hline & & & & & & & & Tshivenda & 5 & Western Cape & 2 \\
\hline & & & & & & & & Xitsonga & 5 & & \\
\hline
\end{tabular}

The collected data were analyzed using the IBM Statistical Package for Social Sciences (SPSS) and Analysis of Moment Structures (AMOS) programs, version 24. The descriptive statistics and Cronbach's alpha values for each of the constructs were computed. The results are presented in Table 2.

Table 2. Descriptive statistics and reliability measures

\begin{tabular}{|l|c|c|c|}
\hline \multicolumn{1}{|c|}{ Constructs } & Means & $\begin{array}{c}\text { Standard } \\
\text { deviations }\end{array}$ & $\begin{array}{c}\text { Cronbach's } \\
\text { alphas }\end{array}$ \\
\hline Perceived relative advantage & 4.99 & 0.93 & 0.93 \\
\hline Attitudes towards mobile banking & 4.93 & 0.91 & 0.83 \\
\hline Perceived ease of use & 4.71 & 1.01 & 0.86 \\
\hline Perceived behavioral control & 4.71 & 1.14 & 0.83 \\
\hline Perceived system quality & 4.49 & 0.93 & 0.92 \\
\hline Subjective norms & 4.10 & 1.32 & 0.88 \\
\hline Perceived integrity & 3.95 & 1.10 & 0.88 \\
\hline Mobile banking usage behavior & 3.88 & 1.46 & 0.75 \\
\hline
\end{tabular}

As shown in Table 2, the Cronbach's alpha values calculated for each of the eight constructs were above the recommended level of 0.60 (Malhotra, 2010), suggesting acceptable internal-consistency reliability. Means above 3.5 were computed for each of the constructs, which, given the Likert scale employed, infers that South African Generation Y students perceive mobile banking as easy to use and as having relative advantages. Moreover, they are likely to take into consideration the opinions of their significant others regarding mobile banking usage and believe that they are in control of mobile banking in terms of their capability and resources needed to use mobile banking. Furthermore, they are of the opinion that mobile banks have integrity and that mobile banking has adequate system quality. In addition, they seem to have a positive attitude towards mobile banking and report behaving actively in terms of their mobile banking usage.

To determine whether there was a relationship between the constructs, a correlation matrix of Pearson's product-moment correlation coefficients was constructed. Table 3 reports on the correlation matrix.
Table 3. Correlation coefficients

\begin{tabular}{|l|c|c|c|c|c|c|c|}
\hline \multicolumn{1}{|c|}{ Constructs } & 1 & 2 & 3 & 4 & 5 & 6 & 7 \\
\hline Perceived ease of use & & & & & & & \\
\hline $\begin{array}{l}\text { Perceived relative advan- } \\
\text { tage }\end{array}$ & $0.332^{*}$ & & & & & & \\
\hline Subjective norms & $0.375^{*}$ & $0.245^{*}$ & & & & & \\
\hline $\begin{array}{l}\text { Perceived behavioral } \\
\text { control }\end{array}$ & $0.369^{*}$ & $0.400^{*}$ & $0.329^{*}$ & & & & \\
\hline Perceived integrity & $0.244^{*}$ & $0.324^{*}$ & $0.195^{*}$ & $0.359^{*}$ & & & \\
\hline Perceived system quality & $0.463^{*}$ & $0.592^{*}$ & $0.410^{*}$ & $0.508^{*}$ & $0.456^{*}$ & & \\
\hline $\begin{array}{l}\text { Attitudes towards mobile } \\
\text { banking }\end{array}$ & $0.328^{*}$ & $0.486^{*}$ & $0.352^{*}$ & $0.527^{*}$ & $0.258^{*}$ & $0.527^{*}$ & \\
\hline $\begin{array}{l}\text { Mobile banking usage } \\
\text { behavior }\end{array}$ & $0.377^{*}$ & $0.434^{*}$ & $0.356^{*}$ & $0.431^{*}$ & $0.405^{*}$ & $0.499^{*}$ & $0.473^{*}$ \\
\hline
\end{tabular}

${ }^{*}$ Statistically significant at $\mathrm{p} \leq 0.01$ (2-tailed).

As indicated in Table 3, at a significance level of $\mathrm{p} \leq 0.01$, there were statistically significant relationships between each of the pairs of constructs, which suggest nomological validity of the measurement theory in this study. Given that the correlation coefficients were all below 0.90 , there was no obvious evidence of multicollinearity (Hair et al., 2010). In addition, the results of the collinearity diagnostics showed that the tolerance values ranged from 0.443 to 0.751 , which is above the 0.10 cut-off level, and the average variance inflation factor (VIF) of 1.64 was below the cut-off of 10 (Pallant, 2010). Owing to the measurement theory, exhibiting nomological validity, together with the unlikelihood of multicollinearity between the constructs, made structural equation modeling possible. Structural equation modeling, using the maximum likelihood method, was employed to test the measurement and structural models. Regarding model fit, although the chisquare statistic is reported on, other fit indices, namely the root mean square error of approximation (RMSEA), the increment-fit-index (IFI), the comparative-fit-index (CFI), and the Tucker-Lewis Index (TLI), were also considered, as the Chi-square is sensitive to sample size (Byrne, 2010). The value of the IFI, CFI and TLI should range between 0.90 and 0.99 , and the value of the RMSEA should be below 0.80 to indicate good fit (Van de Schoot, 2012). 
An eight-factor measurement model was specified for confirmatory factor analysis that included perceived ease of use (three observed variables), perceive relative advantage (three observed variables), subjective norms (three observed variables), perceived behavioral control (three observed variables), perceived integrity (three observed variables), perceived system quality (eight observed variables), attitudes towards mobile banking (three observed variables) and mobile banking usage behavior (three observed variables). For model identification purposes, the first loading on each of the eight factors was fixed at 1.0. Consequently, there were 435 distinct sample moments, and 86 parameters to be estimated, leaving 349 degrees of freedom (df) based on the over-identified model, and a Chi-square value of 797.64 with a probability level equal to 0.000 .

The model was evaluated for any problematic estimates such as negative error variances and standardized factor loadings above 1.0 or below -1.0 (Hair et al., 2010). In order to assess the construct reliability and validity, the composite reliability (CR) and average variance extracted (AVE) scores were computed. The results are outlined in Table 4.

Table 4. Measurement model estimates, construct reliability and validity, and correlation coefficients

\begin{tabular}{|c|c|c|c|c|c|c|c|c|c|c|c|c|}
\hline Constructs & Standardized loading estimates & Error variance estimates & $\mathrm{CR}$ & AVE & $\sqrt{ }$ AVE & F1 & F2 & F3 & F4 & F5 & F6 & F7 \\
\hline \multirow{3}{*}{ Perceived ease of use (F1) } & 0.81 & 0.66 & 0.86 & 0.67 & 0.82 & & & & & & & \\
\hline & 0.81 & 0.66 & & & & & & & & & & \\
\hline & 0.83 & 0.68 & & & & & & & & & & \\
\hline \multirow{3}{*}{ Perceived relative advantage (F2) } & 0.90 & 0.81 & 0.93 & 0.81 & 0.90 & 0.55 & & & & & & \\
\hline & 0.92 & 0.85 & & & & & & & & & & \\
\hline & 0.87 & 0.76 & & & & & & & & & & \\
\hline \multirow{3}{*}{ Subjective norms (F3) } & 0.82 & 0.67 & 0.88 & 0.72 & 0.85 & 0.36 & 0.31 & & & & & \\
\hline & 0.92 & 0.84 & & & & & & & & & & \\
\hline & 0.81 & 0.65 & & & & & & & & & & \\
\hline \multirow{3}{*}{ Perceived behavioral control (F4) } & 0.79 & 0.62 & 0.84 & 0.63 & 0.79 & 0.28 & 0.41 & 0.21 & & & & \\
\hline & 0.81 & 0.66 & & & & & & & & & & \\
\hline & 0.79 & 0.62 & & & & & & & & & & \\
\hline \multirow{3}{*}{ Perceived integrity (F5) } & 0.83 & 0.69 & 0.88 & 0.71 & 0.84 & 0.38 & 0.39 & 0.28 & 0.43 & & & \\
\hline & 0.88 & 0.77 & & & & & & & & & & \\
\hline & 0.81 & 0.66 & & & & & & & & & & \\
\hline \multirow{8}{*}{ Perceived system quality (F6) } & 0.72 & 0.52 & 0.92 & 0.58 & 0.76 & 0.49 & 0.56 & 0.47 & 0.44 & 0.46 & & \\
\hline & 0.80 & 0.64 & & & & & & & & & & \\
\hline & 0.73 & 0.54 & & & & & & & & & & \\
\hline & 0.83 & 0.68 & & & & & & & & & & \\
\hline & 0.80 & 0.65 & & & & & & & & & & \\
\hline & 0.80 & 0.64 & & & & & & & & & & \\
\hline & 0.75 & 0.56 & & & & & & & & & & \\
\hline & 0.65 & 0.43 & & & & & & & & & & \\
\hline \multirow{3}{*}{ Attitudes towards mobile banking (F7) } & 0.80 & 0.64 & 0.83 & 0.62 & 0.79 & 0.65 & 0.58 & 0.50 & 0.45 & 0.51 & 0.57 & \\
\hline & 0.80 & 0.64 & & & & & & & & & & \\
\hline & 0.76 & 0.58 & & & & & & & & & & \\
\hline \multirow{3}{*}{ Mobile banking usage behavior (F8) } & 0.67 & 0.45 & 0.77 & 0.53 & 0.73 & 0.46 & 0.63 & 0.42 & 0.37 & 0.43 & 0.50 & 0.57 \\
\hline & 0.85 & 0.72 & & & & & & & & & & \\
\hline & 0.64 & 0.41 & & & & & & & & & & \\
\hline
\end{tabular}

The evidence in Table 4 indicates that there were no problematic estimates in the measurement model and that there were statistically significant $(\mathrm{p} \leq 0.001)$ associations between each of the observed variables and their respective constructs. Moreover, all the CR values surpassed the recommended level of 0.70 , thus, suggesting the $\mathrm{CR}$ of the constructs. Furthermore, all the standardized loading estimates and AVE values exceeded the recommended 0.50 level, thereby denoting convergent validity (Hair et al., 2010). In addition, all the correlation coefficients were smaller that the square root of the AVE, thereby providing evidence of discriminant validity (Malhotra, 2010). Concerning the model fit indices, while the Chi-square statistic is significant, the other indices indicated acceptable model fit with a RMSEA of 0.06 , an IFI of 0.93 , a CFI of 0.93 , and a TLI of 0.91 .

Based on this measurement model, a structural model was, then, tested. Structural model A was grounded on an extended technology acceptance model (TAM), given that all the factors are believed to have a direct influence on attitudes towards mobile banking, which, in turn, has a direct influence 
on mobile banking usage behavior. This proposition is consistent with other studies of a similar nature (Sayid et al., 2012; Galadima et al., 2014).

While structural model A returned a problematic chi-square statistic $[(851.99(\mathrm{df}=355, \mathrm{p}<0.000)]$, the results of the other indices indicated an acceptable fit of the data to the structural model, with a RMSEA of 0.07, an IFI of 0.92, a TLI of 0.91 and a CFI of 0.92 . Despite the acceptable model fit, the path between both perceived ease of use $(p=0.749>0.05)$ and attitudes towards mobile banking, and perceived integrity
( $p=0.737>0.05)$ and attitudes towards mobile banking was not significant. In addition, although significant, the path between perceived system quality $(p=0.046<0.05)$ and attitudes towards mobile banking was weak. The remaining paths were statistically significant $(\mathrm{p} \leq 0.001)$.

A revised model, structural model $\mathrm{B}$, was tested based on the original measurement model. Table 5 presents the standardized regression coefficients estimated by AMOS for structural model B, and Figure 1 illustrates this structural model.

Table 5. Standardized regression coefficients for the structural paths

\begin{tabular}{|c|c|c|c|c|c|c|c|}
\hline \multicolumn{3}{|c|}{ Paths } & $\beta$ & Unstandardized $\beta$ & SE & $\mathrm{p}$ & Result \\
\hline Perceived relative advantage & $\rightarrow$ & Attitudes towards mobile banking & 0.32 & 0.31 & 0.057 & 0.001 & Significant \\
\hline Subjective norms & $\rightarrow$ & Attitudes towards mobile banking & 0.18 & 0.13 & 0.039 & 0.001 & Significant \\
\hline Perceived behavioral control & $\rightarrow$ & Attitudes towards mobile banking & 0.43 & 0.39 & 0.061 & 0.001 & Significant \\
\hline Attitudes towards mobile banking & $\rightarrow$ & Mobile banking usage behavior & 0.33 & 0.49 & 0.107 & 0.001 & Significant \\
\hline Perceived ease of use & $\rightarrow$ & Mobile banking usage behavior & 0.18 & 0.25 & 0.090 & 0.01 & Significant \\
\hline Perceived integrity & $\rightarrow$ & Mobile banking usage behavior & 0.23 & 0.29 & 0.081 & 0.001 & Significant \\
\hline Perceived system quality & $\rightarrow$ & Mobile banking usage behavior & 0.18 & 0.25 & 0.107 & 0.05 & Significant \\
\hline
\end{tabular}

Note: $\beta$ : beta coefficient; SE: standard error; $p$ : two-tailed statistical significance.

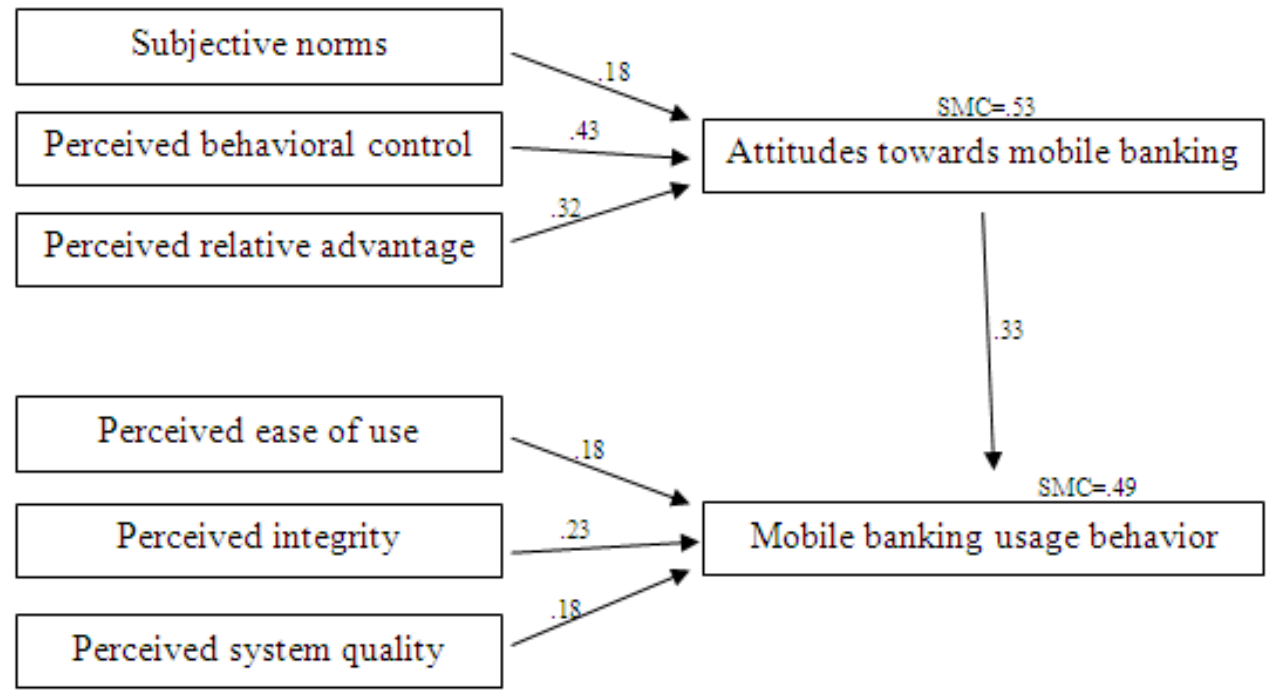

Fig. 1. Structural model B

Note: SMC: squared multiple correlation.

While the Chi-square [808.77 (df=355), $\mathrm{p}<0.000)$ ] remained problematic, the other fit indices produced improved model fit with a RMSEA of 0.06 , an IFI of 0.93 , a TLI of 0.92 and a CFI of 0.93 . When two or more models are compared, it is wise to consider Akaike's information criterion (AIC) and Bozdogan's consistent version of the AIC (CAIC), where smaller values indicate improved model fit (Byrne, 2010). The AIC and the CAIC indices for structural model A were 1011.99 and 1396.88, respectively, whereas an AIC value of 968.77 and a CAIC value of 1353.66 were recorded for structural model $\mathrm{B}$. As it is evident from Table 5, all paths tested were statistically significant $(\mathrm{p} \leq 0.001 ; \mathrm{p} \leq 0.01 ; \mathrm{p} \leq 0.05)$. Perceived relative advan- tage $(\beta=0.32, p<0.001)$, subjective norms $(\beta=0.18$, $p<0.001)$ and perceived behavioral control $(\beta=0.43$, $\mathrm{p}<0.001)$ indirectly influence mobile banking usage behavior via its statistically significant positive influence on attitudes towards mobile banking. Attitudes towards mobile banking $(\beta=0.33, \mathrm{p}<0.001)$, perceived ease of use $(\beta=0.18, p<0.01)$, perceived integrity $(\beta=0.23, p<0.001)$ and perceived system quality $(\beta=0.18, p<0.05)$ have a significant positive influence on mobile banking usage behavior. The squared multiple correlation coefficients (SMCs) indicate that this model explains 53 percent of the variance in attitudes towards mobile banking and 49 percent of the variance in mobile banking usage behavior. 


\section{Discussion}

Through extending the TAM, this study sought to determine the antecedents of attitudes towards and usage behavior of mobile banking amongst Generation Y students in South Africa. Confirmatory factor analysis concluded that that the proposed model is an eight-model structure, which includes perceived ease of use, perceived relative advantage, subjective norms, perceived behavioral control, perceived integrity, perceived system quality, attitudes towards mobile banking and mobile banking usage behavior. The measurement model exhibited composite reliability, construct validity, and acceptable fit to the model, thereby making it suitable for path analysis.

Based on the measurement model, a structural model (structural model A) was tested. This structural model indicated that perceived relative advantage, subjective norms and perceived behavioral control have a significant positive influence on attitudes towards mobile banking. However, the path between perceived ease of use and attitudes towards mobile banking was not significant. While this finding is contrary to what the TAM suggests (Davis, 1989), it is not without grounds, as several studies (Hu et al., 1999; Kleijnen et al., 2004; Akturan and Tezcan, 2012; Aboelmaged and Gebba, 2013) also found perceived ease of use to have no significant influence on attitudes. Similar to perceived ease of use, the path between perceived integrity and attitudes towards mobile banking was not significant. This is not surprising as the literature suggests that perceived integrity is related to trust, expected to influence trust in an innovation rather than attitudes towards the innovation (Nor and Pearson, 2008; Ya'gobi and Rad, 2015). In addition, although significant, the path between perceived system quality and attitudes towards mobile banking was weak. This can be ascribed to the fact that perceived system quality is related to trust, expected to influence trust in a technological innovation rather that attitudes towards the innovation (Zhou, 2011; Zhou, 2013). As such, a revised model, structural model B, was tested based on the original measurement model.

The fit indices of structural model B suggest improved model fit compared to structural model A and indicated that perceived relative advantage, subjective norms and perceived behavioral control indirectly influence Generation Y students' mobile banking usage behavior via their influence on attitudes towards mobile banking. Therefore, Generation Y students who perceive mobile banking as providing relative advantages and those who take into consideration the opinions of their important others concerning mobile banking, and believe that they have the capability and resources needed to undertake mobile banking, tend to have a more positive attitude towards mobile banking. This, in turn, results in them behaving more actively in terms of their mobile banking usage. Moreover, this model indicates that perceived ease of use has a significant positive influence on Generation Y students' mobile banking usage behavior. This finding is in line with the findings of the Daneshgadeh and Yildirim (2014) study. Furthermore, the model indicates that perceived integrity has a significant positive influence on Generation Y students' mobile banking usage behavior. This postulation was based on the premise that integrity influences trust (Nor and Pearson, 2008; Ya'gobi and Rad, 2015), which, in turn, influences usage intention or behavior (Nor and Pearson, 2008), making it reasonable to assert that perceived integrity may have a direct positive influence on usage behavior. In addition, perceived system quality has a significant positive influence on mobile banking usage behavior, which is consistent with the findings of the DeLone and McLean $(1992,2003)$ studies. As such, Generation Y students who perceive mobile banking as easy to use, and those who believe mobile banks have the necessary integrity and perceive mobile banking as having the necessary system quality results in them behaving more actively in terms oftheir mobile banking usage.

These findings suggest that retail banks should strive to simplify their mobile banking offering through considering the incorporation of hands free, voice command capabilities into their current mobile banking system. Retail banks are advised to demonstrate the benefits and value of their mobile banking channel constantly. Retail banks can achieve this through introducing a functionality that creates a summative report tracking customers' spending patterns at certain retailers, thereby also helping customers with their budgeting endeavors. In addition, retail banks should consider the social and environmental benefits of their mobile banking channel. This is likely to stimulate the socially mindful Generation Y cohort's interest in mobile banking. It is also recommended that South African retail banks work towards making digital usage behavior a societal norm, as this might have a noteworthy impact on the demand for technological products and services, including mobile banking.

It is suggested that retail banks ensure that customers experience the same level of service quality within a retail bank branch and when using mobile banking. In doing so, the retail bank may earn a reputation of having integrity, which may bolster customers' trust in both the retail bank branch and their mobile channels, which, in turn, may promote increased mobile banking adoption. In addition, it is advised that retail banks add functionalities to their mobile banking offering that give customers more control over their banking. In this regard, retail banks can consider introducing virtual storage havens that customers can use to store and import digital information. 
Generation $\mathrm{Y}$ is a key current and future customer segment to engage. To build positive and longterm relationships with this segment, retail banks may want to reconsider a number of their strategies, mainly along the dimensions of marketing, banking distribution channels and products. Having a thorough understanding of the values that drive this generation's banking and financial needs and preferences is paramount in this regard.

\section{Limitations and future research}

Caution should be exercised in interpreting the results of the study, as the non-probability convenience sampling method was used. Moreover, a single cross-sectional research design was followed, which provides only a snapshot in time. Using a longitudinal research design could offer value information regarding any changes in the antecedents of attitudes towards and usage behavior of mobile banking amongst South African Generation Y students. In addition, this study depended on self-reporting. Employing an observational research approach may provide a more accurate measure of actual mobile banking attitudes and usage behavior.

\section{Conclusion}

Globally and in South Africa, mobile banking penetration is low. The success of mobile banking is largely depended on customers' adoption thereof, and currently, Generation $\mathrm{Y}$ is leading the charge in adopting all things mobile. Therefore, the purpose of this study was to propose and empirically test an extended TAM of the antecedents of attitudes towards and usage behavior of mobile banking amongst South African Generation Y students. This study concluded that the perceived ease of use of mobile banking, perceived integrity of the mobile bank and the perceived system quality of mobile banking predict Generation Y students' mobile banking usage behavior. In addition, subjective norms, perceived behavioral control and the perceived relative advantage of mobile banking predict attitudes towards mobile banking, which, in turn, predict Generation Y students' mobile banking usage behavior. Understanding the antecedents that positively influence Generation Y students' attitudes towards and usage behavior of mobile banking will assist retail banks in their efforts to tailor their business and marketing strategies effectively towards this cohort, and in doing so, foster increased acceptance of their mobile channels.

\section{References}

1. Aboelmaged, M. G., and Gebba, T. R. (2013). Mobile banking adoption: an examination of technology acceptance model and theory of planned behavior. International Journal of Business Research and Development, 2(1), 35-50.

2. Ajzen, I. (1991). The theory of planned behavior. Organizational Behavior and Human Decision Processes, 50(2), $179-211$.

3. Ajzen, I., and Fishbein, M. (1980). Understanding attitudes and predicting social behavior. New Jersey: Pearson Prentice Hall.

4. Akturan, U., and Tezcan, N. (2012). Mobile banking adoption of the youth market: perceptions and intentions. Marketing Intelligence \& Planning, 30(4), 444-459.

5. Alsajjan, B., and Dennis, C. (2009). Internet banking acceptance model: cross-market examination. Journal of Business Research, 63(9-10), 957-963.

6. Arnaboldi, F., and Claeys, P. (2008). Internet banking in Europe: a comparative analysis. Retrieved from http://www.ub.edu/irea/working_papers/2008/200811.pdf (accessed: 29/08/16).

7. Bevan-Dye, L., and Akpojivi, U. (2015). South African Generation Y students' self-disclosure on Facebook. South African Journal of Psychology, 43(1), 114-129.

8. BuddComm. (2017). South Africa - Mobile Infrastructure, Operators and Broadband - Statistics and Analyses. Retrieved from https://www.budde.com.au/Research/South-Africa-Mobile-Infrastructure-Operators-andBroadband-Statistics-and-Analyses (accessed: 20/03/17).

9. Byrne, B. M. (2010). Structural equation modelling with AMOS: basic concepts, applications and programming. New York: Routledge.

10. Cox, D., Kilgore, T. L., Purdy, T., and Sampath, R. (2008). Catalysts for change: the implications of Gen Y consumers for banks. Retrieved from http://www.deloitte.com/assets/Dcom Shared\%20Assets/Documents/us_fsi_GenY_Consumers_april08.pdf (accessed: 25/03/16).

11. Crabbe, M., Standing, C., Standing, S., and Karjaluoto, $\bar{H}$. (2009). An adoption model for mobile banking in Ghana. International Journal of Mobile Communications, 7(5), 515-543.

12. Daneshgadeh, S., and Yildirim, S. Ö. (2014). Empirical investigation of internet banking usage: the case of Turkey. Procedia Technology, 16, 322-331.

13. Davis, F. D. (1986). A technology acceptance model for empirically testing new end-user information systems: theory and results. Massachusetts: MIS. (Thesis $-\mathrm{PhD}$ ).

14. Davis, F. D. (1989). Perceived usefulness, perceived ease of use, and user acceptance of information technology. MIS Quarterly, 13(3), 319-340.

15. Delafrooz, N., Taleghani, M., Karami, R., and Moradi, A. (2013). Factors affecting the adoption of Internet banking. International Journal of Business and Behavioral Sciences, 3(2), 82-100. 
16. DeLone, W. H., and McLean, E. R. (1992). Information systems success: the quest for the dependent variable. Information Systems Research, 3(1), 60-95.

17. DeLone, W. H., and McLean, E. R. (2003). The DeLone and McLean model of information systems success a tenyear update. Journal of Management Information Systems, 19(4), 9-30.

18. Eastman, J. K., and Liu, J. (2012). The impact of generational cohorts on status consumption: an exploratory look at generational cohort and demographics on status consumption. Journal of Consumer Marketing, 29(2), 93-102.

19. Erasmus, E., Rothmann, S., and Van Eeden, C. (2015). A structural model of technology acceptance. SA Journal of Industrial Psychology, 41(1), 1-12.

20. Ernst and Young. (2009). Mobile money: an overview for global telecommunications operators. Retrieved from http://www.ey.com/Publication/vwLUAssets/Mobile_Money./\$FILE/Ernst\%20\%26\%20Young\%20-

\%20Mobile\%20Money\%20-\%2015.10.09\%20(single\%20view).pdf (accessed: 25/03/16).

21. Ernst and Young. (2017). Global banking outlook 2017: uncertainty is no excuse for inaction. Retrieved from http:/www.ey.com/Publication/vwLUAssets/EY-global-banking-outlook-2017/\$FILE/EY-global-bankingoutlook-2017.pdf (accessed: 23/05/17).

22. FinScope South Africa. (2015). FinScope South Africa 2015 . Retrieved from http://www.finmark.org.za/wpcontent/uploads/2016/03/Broch_FinScopeSA2015_Consumersurvey_FNL.pdf (accessed: 20/03/17).

23. Fishbein, M., and Ajzen, I. (1975). Belief, attitudes, intention and behavior: an introduction to theory and research. Phillippines: Addison-Wesley.

24. Galadima, T. O., Akinyemi, I. O., and Asani, E. O. (2014). The impact of knowledge-based trust (Kbt) on the adoption and acceptability of cashless economy in Nigeria. International Journal of Computer Science \& Information Technology, 6(2), 171-180.

25. Gao, T., Rohm, A. J., Sultan, F., and Huang, S. (2012). Antecedents of consumer attitudestoward mobile marketing: a comparative study of youth markets in the United Statesand China. Thunderbird International Business Review, 54, 211-224.

26. Greaves, M., Zibarras, L. D., and Stride, C. (2013). Using the theory of planned behavior to explore environmental behavioral intentions in the workplace. Journal of Environmental Psychology, 34(1), 109-120.

$\begin{array}{lllll}\text { 27. GSMA. (2017). The mobile economy 2017. Retrieved } & \text { from }\end{array}$ $\mathrm{https}$ :/www.gsmaintelligence.com/research/?file=9e927fd6896724e7b26f33f61db5b9d5\&download (accessed: 20/03/17).

28. Gu, J. C., Lee, S. C., and Suh, Y. H. (2009). Determinants of behavioral intention to mobile banking. Expert Systems with Applications, 36(9), 11605-11616.

29. Gumussoy, C. A., Calisir F., and Bayram, A. (2007). Understanding the behavioral intention to use ERP systems: an extended technology acceptance model. Proceedings of the International Conference on Industrial Engineering and Engineering Management (IEEE), Singapore.

30. Guritno, R. S., and Siringoringo, H. (2013). Perceived usefulness, ease of use, and attitude towards online shopping usefulness towards online airlines ticket purchase. Procedia - Social and Behavioral Sciences, 81, 212-216.

31. Hair, J. F., Black, W. C., Babin, B. J., and Anderson, R. E. (2010). Multivariate data analysis: a global perspective. New Jersey: Pearson Prentice Hall.

32. Hanafizadeh, P., Behboudi, M., Koshksaray, A. A., and Tabar, M. J. S. (2014). Mobile-banking adoption by Iranian clients. Telematics and Informatics, 31(1), 62-78.

33. Hu, P. J., Chau, P. Y. K., Lui Sheng, O. R., and Tam, K. Y. (1999). Examining the technology acceptance model using physician acceptance of telemedicine technology. Journal of Management Information Systems, 16(2), 91-112.

34. IT news Africa. (2015). Will digital finance play a bigger role in SA in 2015? Retrieved from http://www.itnewsafrica.com/2015/02/will-digital-finance-play-a-bigger-role-in-sa-in-2015/ (accessed: 12/03/16).

35. Kanchan, A., Banerjee, B., Wilson, D., and Sullivan, W. (2012). Trends in retail banking channels: improving client service and operating costs. Retrieved from https://www.capgemini.com/resource-fileaccess/resource/pdf/Trends_in_Retail_Banking_Channels_Improving_Client_Service_and_Operating_Costs.pdf (accessed: 12/03/16).

36. Kane, S. (2016). Gen Y/Millennial lawyers in the legal workplace. What are the characteristics of Generation Y/millennials? Retrieved from https:/www.thebalance.com/gen-y-millennial-lawyers-in-the-legal-workplace2164559 (accessed: 12/03/17).

37. Khasawneh, M. H. A. (2015). A mobile banking adoption model in the Jordanian market: an integration of TAM with perceived risks and perceived benefits. Journal of Internet Banking and Commerce, 20(3), 1-26.

38. Kleijnen, M., Wetzels, M., and de Ruyter, K. (2004). Consumer acceptance of wireless finance. Journal of Financial Services Marketing, 8(3), 206-217.

39. Koh, C. E., Prybutok, V. R., Ryan, S. D., and Wu, Y. (2010). A model for mandatory use of software technologies: an integrative approach by applying multiple levels of abstraction of informing science. Informing Science: The International Journal of an Emerging Transdiscipline, 13, 177-203.

40. KPMG. (2015a). Digital offerings in mobile banking - the new normal. Retrieved from https://www.kpmg.com/channelislands/en/IssuesAndInsights/ArticlesPublications/Documents/Digital\%20offering s\%20in\%20mobile\%20banking\%20-\%20May\%202015.pdf (accessed: 08/08/16).

41. KPMG. (2015b). Mobile banking 2015. Retrieved from https://www.kpmg.com/UK/en/IssuesAndInsights/ ArticlesPublications/Documents/PDF/mobile-banking-report-2015.pdf (accessed: 08/08/16). 
42. KPMG South Africa. (2014). SA banking is top notch. Retrieved from http://www.sablog.kpmg.co.za/2014/09/sabanking-top-notch/ (accessed: 08/08/16).

43. Lee, K. S., Lee, H. S., and Kim, S. Y. (2007). Factors influencing the adoption behavior of mobile banking: a South Korean perspective. Journal of Internet Banking and Commerce, 12(2), 1-9.

44. Lee, M. C. (2009). Factors influencing the adoption of internet banking: an integration of TAM and TPB with perceived risk and perceived benefit. Electronic Commerce Research and Applications, 8(3), 130-141.

45. Lin, H. F. (2011). An empirical investigation of mobile banking adoption: the effect of innovation attributes and knowledge-based trust. International Journal of Information Management, 31(3), 252-260.

46. Maduku, D. K. (2011). Understanding retail bank customers' attitude towards and usage of cell phone and Internet banking services in Gauteng, South Africa. Johannesburg: UJ. (Dissertation - MCom).

47. Maduku, D. K. (2013). Predicting retail customers' attitude towards Internet banking service in South Africa. Southern African Business Review, 17(3), 76-100.

48. Malhotra, N. K. (2010). Marketing research: an applied orientation. New Jersey: Pearson Prentice Hall.

49. Markert, J. (2004). Demographics of age: generational and cohort confusion. Journal of Current Issues and Research in Advertising, 26(2), 11-25.

50. Marous, J. (2013). Banking leaders discuss 2014 strategic planning priorities. Retrieved from http://thefinancialbrand.com/37129/banking-credit-union-2014-strategic-planning-priorities/ (accessed: 14/08/16).

51. Martins, C., Oliveira, T., and Popovič, A. (2014). Understanding the Internet banking adoption: a unified theory of acceptance and use of technology and perceived risk application. International Journal of Information Management, 34(1), 1-13.

52. Mazhar, F., Rizwan, M., Fiaz, U., Ishrat, S., Razzaq, M. S., and Khan, T. N. (2014). An investigation of factors affecting usage and adoption of Internet \& mobile banking in Pakistan. International Journal of Accounting and Financial Reporting, 4(2), 478-501.

53. Niaura, A. (2013). Using the theory of planned behavior to investigate the determinants of environmental behavior among youth. Environmental Research, Engineering and Management, 1(63), 74-81.

54. Nor, K. M., and Pearson, J. M. (2008). An exploratory study into the adoption of Internet banking in a developing country: Malaysia. Journal of Internet Commerce, 7(1), 29-73.

55. Olatokun, W., and Owoeye, O. J. (2012). Influence of individual, organizational and system factors on attitude of online banking users. Proceedings of Informing Science \& IT Education Conference, 389-403.

56. Pallant, J. (2010). SPSS survival manual: a step by step guide to data analysis using SPSS. England: Open University Press.

57. Park, S. Y. (2009). An analysis of the technology acceptance model in understanding university students' behavioral intention to use e-learning. Educational Technology \& Science, 12(3), 150-162.

58. Püschel, J., and Mazzon, J. A. (2010). Mobile banking: proposition of an integrated adoption intention framework. International Journal of Bank Marketing, 28(5), 389-409.

59. PwC (PricewaterhouseCoopers). (2011). When the growing gets tough: how retail banks can thrive in a disruptive, mobile, regulated world. Retrieved from http://www.pwc.com/en_US/us/financialservices/publications/viewpoints/assets/viewpoint-when-the-growing-gets-tough.pdf (accessed: 08/08/16).

60. PwC (PricewaterhouseCoopers). (2014). Retail banking 2020 - evolution or revolution? Retrieved from http://www.pwc.com/et_EE/EE/publications/assets/pub/pwc-retail-banking-2020-evolution-or-revolution.pdf (accessed: 08/08/16).

61. Saibaba, S., and Murthy, T. N. (2013). Factors influencing the behavioral intention to adopt Internet banking: an empirical study in India. Journal of Arts, Science \& Commerce, 4(1), 77-91.

62. Sayid, O., Echchabi, A., and Aziz, H. A. (2012). Investigating mobile money acceptance in Somalia: an empirical study. Pakistan Journal of Commerce \& Social Sciences, 6(2), 269-281.

63. Schiffman, L. G., Kanuk, L. L., and Wisenblit, J. (2010). Consumer behavior. Pearson Prentice Hall.

64. Schlitzkus, L. L., Schenarts, K. D., and Schenarts, P. J. (2010). Is your residency program ready for Generation Y? Journal of Surgical Education, 67(2), 108-111.

65. Shanmugam, A., Savarimuthu, M. T., and Wen, T. C. (2014). Factors affecting Malaysian behavioral intention to use mobile banking with mediating effects of attitude. Academic Research International, 5(2), 236-253.

66. Sharif, K. J., Kalafatis, S. P., and Samouel, P. (2005). Cognitive and behavioral determinants of trust in small and medium-sized enterprises. Journal of Small Business \& Enterprise Development, 12(3), 409-421.

67. Sharp, J. H. (2007). Development, extension, and application: a review of the technology acceptance model. Information Systems Education Journal, 5(9), 1-11.

68. Shezi, L. (2016). SA's 26.8 million internet users spend almost three hours a day on social media. Retrieved from http://www.htxt.co.za/2016/04/29/the-stuff-south-africa-26-8-mil-internet-users-spend-most-their-time-doingonline/ (accessed: 20/03/17).

69. Sommer, L. (2011). The Theory of Planned Behavior and the impact of past behavior. International Business \& Economics Research Journal, 10(1), 91-110.

70. Special, W. P., and Li-Barber, K. T. (2012). Self-disclosure and student satisfaction with Facebook. Computers and Human Behavior, 28, 624-630.

71. Standard Bank. (2015). Future of banking in Africa is mobile. Retrieved from http://community.standardbank.co.za/t5/Blog/Future-of-banking-in-Africa-is-mobile/ba-p/921 (accessed: 06/08/16). 
72. Surendran, P. (2012). Technology acceptance model: a survey of literature. International Journal of Business and Social Research, 2, 175-178.

73. Tome, L., Johnston K. A., Meadows, A., and Nyemba-Mudenda, M. (2014). Barriers to open source ERP adoption in South Africa. The African Journal of Information Systems, 6, 26-47.

74. Van de Schoot, R., Lugtig, P., and Hox, J. (2012). A checklist for testing measurement invariance. European Journal of Developmental Psychology, 9, 486-492.

75. Wessels, L., and Drennan, J. (2010). An investigation of consumer acceptance of m-banking. International Journal of Bank Marketing, 28(7), 547-568.

76. Ya'gobi, N. M., and Rad, Z. N. (2015). Effective behavioral factors on customers' intention to use mobile banking services. Case study: Saderat bank branches of Mashhad. Arth Prabandh: A Journal of Economics and Management, 4(2), 128-143.

77. Zhou, T. (2011). An empirical examination of initial trust in mobile banking. Internet Research, 21(5), 527-540.

78. Zhou, T. (2013). An empirical examination of continuance intention of mobile payment services. Decision Support Services, 54(2), 1085-1091. 